\title{
Apa yang Mempengaruhi Investor Sukuk Negara dalam Menentukan Liquidity Premium?
}

\author{
* Email: dihandayani@kemenkeu.go.id \\ a Direktorat Pembiayaan Syariah, \\ DJPPR, Kementerian Keuangan. JI. DR. \\ Wahidin Raya No. 1, Jakarta 10710 \\ ${ }^{\beta 1}$ Departemen Ekonomi dan Keuangan \\ Syariah, Bank Indonesia. JI $\mathrm{MH}$ \\ Thamrin No 2, Jakarta 10350. \\ B2 Politeknik Keuangan Negara STAN, \\ BPPK, Kementerian Keuangan. Jl. \\ Bintaro Utama Sektor V, Bintaro Jaya, \\ Tangerang Selatan, 15222.
}

Ihwan Hadi Sunarno ${ }^{\alpha}$, Rifki Ismal ${ }^{\beta 1}$, \& Dian Handayani ${ }^{\beta 2^{*}}$

Riwayat artikel:

- Diterima 12 April 2019

- Direvisi 24 Oktober 2019

- Disetujui 9 Desember 2019

- Tersedia online 20 April 2020

Keywords:

sukuk; liquidity premium; trading cost; market depth.

JEL Classification :

$\mathrm{G} 12, \mathrm{H} 63, \mathrm{C} 33$

\begin{abstract}
Abstrak
Sukuk Negara diterbitkan sebagai upaya diversifikasi pembiayaan APBN sekaligus untuk pengembangan pasar keuangan syariah. Sejak 2008, selain Surat Utang Negara (SUN), Pemerintah memiliki alternatif instrumen pembiayaan APBN yang menyasar investor syariah. Namun berdasarkan hasil pengamatan, untuk tenor yang sama, Sukuk Negara memiliki rata-rata expected return (yield) lebih tinggi dibandingkan SUN. Penelitian ini bertujuan menganalisis faktor-faktor yang memengaruhi investor dalam menentukan liquidity premium Sukuk Negara terhadap SUN. Dimensi likuiditas seperti trading cost dan market depth serta terms Sukuk Negara, seperti time to maturity dan kupon, digunakan untuk menganalisis pengaruh tersebut. Hasil penelitian terhadap seri PBS003 dan PBS004 menunjukkan bahwa dimensi trading cost berpengaruh terhadap kedua seri tersebut. Namun untuk PBS003, terlihat bahwa dalam jangka panjang (t-5) investor lebih mengharapkan volatilitas pasar. Faktor likuiditas dalam memperhitungkan risiko menjadi pertimbangan investor dalam jangka pendek (t-3). Adapun dimensi market depth berpengaruh signifikan terhadap liquidity premium PBS004 namun tidak signifikan terhadap PBS003. Dimensi kedalaman pasar 4 bulan sebelumnya (t-4) signifikan memengaruhi liquidity premium PBS004. Tidak adanya market maker diduga menjadi salah satu penyebab lag dari dimensi kedalaman pasar. Terms Sukuk Negara signifikan mempengaruhi keputusan investor dalam menentukan liquidity premium.
\end{abstract}

\begin{abstract}
In addition to developing Islamic financial market, Sovereign Sukuk is issued as State Budget financing diversification. Since 2008, Government has an alternative budget financing instrument besides Government Securities (SUN) which targeting Islamic investors. Hence, from an observation, Sovereign Sukuk has a higher average expected return (yield) than SUN for the same tenor. This study aims to analyze factors that influence investors in determining liquidity premium of Sovereign Sukuk on SUN. The liquidity
\end{abstract} dimensions such as trading costs and market depth and Sovereign Sukuk terms such as time to maturity and coupons are used to analyze these influences. The results of the study on PBS003 and PBS004 series indicate that the trading cost dimension affects the two series. However, for PBS003, it appears that in the long term ( $\mathrm{t}-5)$ investors expect market volatility. The liquidity factor in calculating risk is considered by investors in the short term ( $\mathrm{t}-3)$. The market depth dimension has a significant effect on PBS004 premium liquidity but is not significant for PBS003. The market depth dimension of the previous 4 months ( $t-4)$ significantly affected PBS004's premium liquidity. The absence of a market maker is thought to be one of the causes of lag in the dimensions of market depth. Sovereign Sukuk terms significantly influence investor decisions in determining premium liquidity. 


\section{PENDAHULUAN}

Kebutuhan pembiayaan APBN mendorong Pemerintah mengembangkan berbagai alternatif sumber pembiayaan. Sebagai upaya mengurangi ketergantungan terhadap pinjaman asing, Pemerintah menerbitkan Surat Berharga Negara dalam bentuk Surat Utang Negara (SUN). Seiring dengan berkembangnya pasar keuangan syariah, dibutuhkan instrumen pemerintah yang dapat menjadi benchmark untuk mendorong perkembangannya. Surat Berharga Syariah Negara (SBSN) atau Sukuk Negara lahir pada 2008 untuk menjawab berbagai kebutuhan tersebut.

Sejak itu, Pemerintah secara reguler menerbitkan Sukuk Negara dengan total nominal yang terus meningkat setiap tahunnya. Porsi penerbitan Sukuk Negara terhadap SUN juga terus meningkat yang menunjukkan bahwa instrumen ini semakin menjadi andalan Pemerintah untuk memenuhi kebutuhan pembiayaan APBN. Jika bertambahnya nominal penerbitan menunjukkan meningkatnya permintaan pasar, hal tersebut tidak terefleksi pada tingkat imbal hasil (yield) Sukuk Negara yang secara rata-rata masih lebih tinggi dibandingkan SUN dalam tenor yang sama. Hal tersebut menimbulkan konsekuensi lebih tingginya biaya penerbitan Sukuk Negara dibandingkan SUN. Investor diduga menetapkan sejumlah liquidity premium terhadap Sukuk Negara. Tabel 1 menunjukkan perbandingan yield antara SUN dengan Sukuk Negara dalam tenor yang berkesesuaian.

TABEL-1: Selisih Imbal Hasil (Yield) Sukuk Negara dengan SUN

\begin{tabular}{|c|c|c|c|c|c|c|c|c|c|}
\hline \multirow{2}{*}{ No } & \multicolumn{4}{|c|}{ SBSN } & \multicolumn{4}{|c|}{ SUN } & \multirow[b]{2}{*}{ Selisih (bps) } \\
\hline & Series & First Issue & Maturity & Average of Yield & Series & Maturity & First Issue & Average of Yield & \\
\hline & 1 IFR0002 & 26-Aug-08 & 15-Aug-18 & 7.0511 & FRO038 & 15-Aug-18 & 24-Aug-06 & 6.4511 & 60 \\
\hline & IFR0006 & 1-Apr-10 & 15-Mar-30 & 8.1511 & FRO052 & 15-Aug-30 & 20-Aug-09 & 7.9915 & 15.96 \\
\hline & \begin{tabular}{|l|l|} 
IFR0007 \\
\end{tabular} & 21-Jan-10 & 15-Jan-25 & 7.821 & FR0040 & 15-Sep- 25 & 21-Sep-06 & 7.6702 & 15.08 \\
\hline & A IFR0010 & 3-Mar-11 & 15-Feb-36 & 8.3287 & FRO072 & 15-May-36 & 9-Jul-15 & 8.128 & 20.07 \\
\hline & PBS001 & 16-Feb-12 & 15-Feb-18 & 7.7099 & FR0032 & 15-Jul-18 & 1-Sep-05 & 6.3933 & 131.66 \\
\hline & PBSO02 & $2-F e b-12$ & $15-\operatorname{Jan}-22$ & 7,8373 & FRO061 & 15-May-22 & 6-0ct-11 & 7.1571 & 68.02 \\
\hline & PBSO03 & 2-Feb-12 & 15-Jan-27 & 8.0834 & FR0059 & 15-May-27 & 15-Sep-11 & 7.5319 & 55.15 \\
\hline & PBSO04 & 16-Feb-12 & 15-Feb-37 & 8.6349 & FROO45 & 15-May-37 & 24-May-07 & 8.2519 & 38.3 \\
\hline & PBS006 & 19-Sep-13 & $15-\operatorname{Sep}-20$ & 7.307 & FR0031 & 15 -Nov- 20 & 16-Jun-05 & 7.2248 & 8.22 \\
\hline 10 & PBS009 & 30-Jul-15 & 25-Jan-18 & 6.0503 & FRO066 & 15-May-18 & 25-Oct-12 & 6.2691 & .21 .88 \\
\hline 11 & PBS011 & 14-Jan-16 & 15-Aug- 23 & 7.8214 & FR0039 & 15-Aug-23 & 24-Aug-06 & 7.5124 & 30.9 \\
\hline 12 & 2 PBS012 & 28-Jan-16 & 15-Nov-31 & 8.2729 & FR0054 & 15-Jul-31 & 22-Jul-10 & 8.0394 & 23.35 \\
\hline 13 & \begin{tabular}{|l|l|} 
PBS013 \\
\end{tabular} & 6-0ct-16 & 15-May-19 & 6.9772 & FR0069 & 15-Apr-19 & 29-Aug-13 & 6.8041 & 17.31 \\
\hline 14 & PBS014 & 6-0ct-16 & 15-May-21 & 7.4443 & FROO34 & 15-Jun-21 & 26-Jan-06 & 7.3073 & 13.7 \\
\hline
\end{tabular}

Sumber: Indonesia Bonds Pricing Agency (IBPA) dan diolah

*Data per 16 Februari 2017

Sukuk memiliki karakteristik dasar yang berbeda dengan obligasi. Obligasi merupakan surat pernyataan utang, sedangkan sukuk merupakan pernyataan kepemilikan terhadap suatu aset atau proyek atau portofolio yang menjadi underlying penerbitan sukuk. Akan tetapi, secara operasional di pasar keuangan, sukuk tidak jauh berbeda dengan obligasi. Hingga saat ini, Sukuk Negara yang diterbitkan pemerintah bersifat asset-based, bukan asset-backed. Pembayaran kewajiban yang timbul dari penerbitan Sukuk Negara dijamin oleh negara dalam UndangUndang No. 19 tahun 2008 tentang Surat Berharga Syariah Negara maupun Undang-Undang Anggaran Pendapatan dan Belanja Negara (APBN) setiap tahunnya. Dengan demikian, investor seharusnya tidak memiliki isu terhadap performa aset maupun proyek yang menjadi underlying penerbitan Sukuk Negara.

Ketika berinvestasi pada surat berharga, seperti obligasi, harga dan yield menjadi dua variabel penting yang menjadi pertimbangan investor. Kedua variabel tersebut saling berhubungan tetapi bersifat negatif (inverse relationship), yakni saat yield meningkat, harganya akan turun, dan sebaliknya. Faktor lainnya yang mempengaruhi harga obligasi yaitu kondisi makroekonomi, kondisi industri dan emiten, kinerja emiten, struktur instrumen, dan likuiditas 
pasar. Faktor likuiditas berpengaruh terhadap imbal hasil obligasi karena faktor likuiditas merupakan salah satu risiko investor ketika berinvestasi pada obligasi. Semakin besar likuiditas, semakin rendah yield yang akan diharapkan investor (Fabozzi, 2000).

Likuiditas merupakan konsep multidimensi yang kerap menjadi obyek penelitian. Dipelopori oleh Kyle (1985) dan dilanjutkan oleh Harris (1990), aspek likuiditas pasar keuangan dapat dilihat dari empat dimensi yaitu tightness, resiliency, depth, dan immediacy. Penelitian-penelitian berikutnya banyak mengajukan berbagai indikator untuk pengukurannya di tengah kendala sensitivitas ketersediaan informasi dan trading environment (Rouetbi \& Mamoghli, 2014). Dick-nielsen et al. (2012) menggunakan beberapa pengkuran yaitu amihud measure, roll measure, imputed roundtrip cost, dan turnover. Black et al. (2016) menggunakan dimensi trading cost yang digambarkan melalui bid-ask spread, market depth dimension yang digambarkan dengan amihud measure, dan resilencies dimension yang digambarkan melalui beta dari perubahan kepemilikan dealer. Kedua penelitian tersebut berupaya melihat perbedaan obligasi korporasi Amerika dan guaranteed bonds dengan US Treasury.

Perbedaan yield antara instrumen konvensional (obligasi) dengan instrumen syariah (sukuk) terus menjadi perhatian negara yang secara aktif menerbitkan kedua instrumen tersebut. Di Malaysia yang pemerintahnya memiliki program penerbitan Sukuk dan memiliki pasar sukuk korporasi yang aktif, ditemukan perbedaan signifikan antara rata-rata yield obligasi dengan sukuk, yaitu premi atau selisih lebih antara keduanya disebabkan karena adanya liquidity premium dari investor (Ariff \& Safari, 2012; Ariff et al., 2013; Ariff et al., 2017). Karatas \& Nienhaus (2015) mengakui hasil penelitian-penelitian terdahulu tersebut dan memberikan eksplorasi lebih mendalam mengenai kondisi pasar dan perilaku investor sukuk, baik yang berasal dari konvensional maupun investor syariah. Adanya bias dalam hal konsistensi data serta faktor intervensi pemerintah yang memberikan dukungan politis terhadap pengembangan instrumen syariah, menjadi tantangan dalam upaya membandingkan performa sukuk dengan obligasi.

Sepanjang pengetahuan peneliti, jumlah penelitian dan publikasi di Indonesia mengenai yield dan harga sukuk masih terbatas. Bunaidy (2012) berupaya melakukan analisis deskriptif likuiditas obligasi pemerintah termasuk sukuk dari dimensi biaya transaksi, dampak harga, dan kedalaman pasar. Khusus Sukuk Negara, Nurhasanah (2011) menemukan bahwa tidak ada hubungan antara likuiditas (volume perdagangan) dan harga, sedangkan frekuensi perdagangan dan bid-ask spread mempengaruhi likuiditas sukuk. Tiga tahun kemudian penelitian Rifaldi (2014) menyimpulkan bahwa volume, frekuensi perdagangan, tingkat imbalan, dan time to maturity (TTM) mempengaruhi harga sukuk. Selain periode waktu yang berbeda, kedua penelitian tersebut menggunakan obyek Sukuk Negara yang berbeda pula, yaitu Nurhasanah (2011) meneliti seri IFR dan SR, sedangkan Rifaldi (2014) meneliti seri PBS. Dengan data yang lebih baru, Rosetika (2018) melakukan penelitian dan menemukan pengaruh outstanding, time to maturity dan umur terhadap likuiditas Sukuk Negara. Dalam halnya sukuk korporasi, penelitian yang telah dilakukan terkait yield dan harga juga terbatas. Masitoh (2016) menemukan pengaruh faktor likuiditas yaitu maturity dan volume perdagangan terhadap yield spread, sedangkan Priyambodo (2018) lebih menyoroti performa kinerja perusahaan terhadap yield.

Tingginya imbal hasil Sukuk Negara terhadap SUN sebagaimana ditunjukkan pada Tabel 1 diduga karena investor menambahkan premi sebagai kompensasi dari faktor likuiditas (liquidity premium). Hal tersebut dilakukan investor karena Sukuk Negara dianggap tidak likuid di pasar sekunder. Berdasarkan latar belakang tersebut, penelitian ini berupaya menganalisis faktor-faktor yang mempengaruhi liquidity premium Sukuk Negara terhadap SUN, yang keduanya merupakan instrumen Surat Berharga Negara yang diterbitkan dan dijamin pemerintah. Penelitian ini menggunakan dimensi likuiditas dari aspek biaya transaksi (trading cost dimesion) dan market depth dimension. Hasil analisis tersebut diharapkan dapat menghasilkan rekomendasi strategi pengembangan pasar sukuk kepada pemerintah selaku penerbit serta Self 
Regulatory Organizations (SRO) sebagai pihak yang memiliki kewenangan dalam regulasi pasar keuangan.

\section{TINJAUAN PUSTAKA}

\subsection{Sukuk Negara dan SUN}

Sukuk Negara adalah Surat Berharga Negara yang diterbitkan berdasarkan prinsip syariah, sebagai bukti atas bagian penyertaan terhadap Aset SBSN, baik dalam mata uang rupiah maupun valuta asing (Undang-Undang Nomor 19 tahun 2008 tentang Surat Berharga Syariah Negara). Sedangkan, Surat Utang Negara (SUN) adalah surat berharga yang berupa surat pengakuan utang dalam mata uang Rupiah maupun valuta asing yang dijamin pembayaran bunga dan pokoknya oleh Negara Republik Indonesia, sesuai dengan masa berlakunya (Undang-Undang Nomor 24 tahun 2002 tentang Surat Utang Negara).

Menurut Siamat \& Suminto (2015), prinsip dasar kedua instrumen Surat Berharga Negara tersebut berbeda dimana Surat Berharga Syariah Negara (SBSN) atau Sukuk Negara diterbitkan berdasarkan prinsip syariah sebagai bukti kepemilikan/penyertaan terhadap aset sedangkan SUN merupakan surat pernyataan utang tanpa syarat dari penerbit. Penerbitan Sukuk Negara membutuhkan underlying asset yang dapat berupa aset berwujud, nilai manfaat aset, jasa, proyek/kegiatan investasi dengan landasan syariah berupa fatwa dan opini syariah. Sedangkan SUN tidak memiliki semua itu. Dari sisi penggunaan dana, tidak ada batasan penggunaan dana dari hasil penerbitan SUN. Penggunaan dana hasil penerbitan Sukuk Negara tidak dapat digunakan untuk sesuatu yang bertentangan dengan prinsip syariah. Perbedaan lainnya antara Sukuk Negara dengan SUN adalah dari sisi return. Return Sukuk Negara dapat berupa imbalan yang berasal dari sewa, bagi hasil, fee, margin, tergantung underlying akad yang digunakan, serta terdapat pula potensi capital gain. Sedangkan return SUN berupa bunga dan potensi capital gain. Ketika SUN dijual di pasar sekunder, investor melakukan penjualan atas surat utang. Perdagangan Sukuk Negara di pasar sekunder merupakan transaksi atas kepemilikan aset berwujud yang merupakan dasar penerbitan Sukuk Negara tersebut. Investor Sukuk Negara mencakup investor konvensional dan syariah, sedangkan investor SUN hanya investor konvensional saja.

Pada periode awal penerbitan, Sukuk Negara diterbitkan dengan menggunakan underlying asset berupa Barang Milik Negara (BMN) dengan akad Ijarah Sale and Lease Back. Instrumen yang diterbitkan memberikan imbal hasil yang bersifat tetap (fixed rate), dan pada awal kemunculannya seri Sukuk Negara dinamakan IFR (ijarah fixed rate). Sebagai upaya diversifikasi investor dengan menyasar investor ritel, pada 2009 pemerintah menerbitkan seri Sukuk Ritel (SR) yang saat itu juga menggunakan underlying asset berupa BMN (Siamat $\&$ Suminto, 2015).

Dalam perkembangannya, sebagai upaya diversifikasi underlying asset, pada tahun 2011 pemerintah meluncurkan seri Project-Based Sukuk (PBS) dengan akad ijarah asset to be leased yang menggunakan underying berupa proyek/kegiatan pemerintah. Akad ijarah asset to be leased selanjutnya tidak hanya digunakan untuk seri-seri PBS, tetapi juga SR dan SNI yang diterbitkan di pasar internasional dalam mata uang USD atau Global Sukuk. Inovasi terus dilakukan. Selanjutnya, pada tahun 2014 pemerintah juga mulai menggunakan akad wakalah yang pertama kali digunakan untuk penerbitan Sukuk Negara di pasar global untuk seri SNI24 yang jatuh tempo pada tahun 2024. Upaya tersebut dimaksudkan untuk terus menjaga kontinuitas penerbitan Sukuk Negara. Hal tersebut diperkuat pula oleh hasil penelitian Rifaldi (2014) dan Rosetika (2018) yang merekomendasikan konsistensi penerbitan Sukuk Negara untuk mendukung pengembangan pasar keuangan syariah.

Seri PBS yang diterbitkan Pemerintah Indonesia bersifat asset-based, bukan asset-backed. Menurut Haneef (2009) asset-based sukuk merupakan mayoritas struktur Sukuk yang banyak beredar saat ini. Asset-based sukuk memiliki underlying asset yang sesuai dengan prinsip syariah, tetapi pemilik sukuk tidak memiliki security interest atau klaim legal atas agunan yang dijaminkan terhadap underlying sukuk. Asset-based sukuk diperlakukan serupa dengan senior 
unsecured securities. Sementara itu, asset-backed sukuk serupa covered bonds, yakni investor dapat mengajukan klaim legal terhadap aset jika terjadi default (Jobst et al., 2008)

Perbedaan antara asset-based dan asset-backed sukuk banyak dibahas (Jobst et al, 2008; Brugnoni, 2008; Haneef, 2009) yang diskusinya bermuara pada bagaimana seharusnya investor memperlakukan sukuk (pricing). Temuan Nienhaus \& Karatas (2016) menunjukkan bahwa di negara penerbit sukuk dan obligasi seperti Malaysia, Turki, dan Hong Kong, investor tidak memberikan perlakuan berbeda yang signifikan antara sukuk dan obligasi. Lebih lanjut lagi, temuan di Indonesia menunjukkan bahwa yield sukuk secara konsisten lebih tinggi dibandingkan obligasi yaitu yield curve keduanya bergerak paralel, yang berarti pergerakan keduanya dipicu oleh faktor-faktor yang sama. Dari temuan tersebut Nienhaus \& Karatas (2016) menyimpulkan bahwa tidak ada perbedaan antara market behavior sukuk dan obligasi.

\subsection{Infrastruktur Pasar}

Pembahasan mengenai infrastruktur pasar Sukuk Negara tidak terlepas dari infrastruktur pasar SUN yang sudah lebih dulu terbentuk. Sejarah penerbitan SUN berawal dari krisis keuangan Asia tahun 1998 yang membuahkan rekomendasi para penentu kebijakan di seluruh dunia mengenai diperlukannya pasar obligasi domestik. Untuk itu, diperlukan strategi pengembangan obligasi pemerintah yang merupakan tulang punggung pasar obligasi domestik. SUN yang merupakan surat pernyataan utang dari Pemerintah diperdagangkan atas dasar kepercayaan dan kredibilitas Pemerintah sehingga penguatan kebijakan makro dan moneter, serta pengembangan pasar obligasi domestik yang berkesinambungan menjadi sangat penting dalam menjaga kredibilitas Pemerintah (World Bank, 2001 dan Fabozzi, 2008 dalam Direktorat Jenderal Pengelolaan Pembiayaan dan Risiko, 2016).

Pengembangan pasar obligasi domestik yang berkesinambungan menjadi tantangan bagi pemerintah negara-negara berkembang. Tidak ada cara yang mudah sebagaimana diungkapkan Turner (2002), bahkan salah satu pendapat yang umum adalah menyerahkan pada mekanisme pasar, yaitu likuiditas akan terjadi jika perdagangan surat berharga antar lembaga keuangan tidak diatur oleh regulasi. Mohanty (2002) termasuk yang meyakini bahwa pemerintah (bank sentral dan treasury) perlu melakukan langkah awal untuk memicu terjadinya pasar, dan terus memastikan pasar berjalan sesuai harapan.

Likuiditas pasar sekunder merupakan fitur penting pasar obligasi pemerintah. Likuiditas menjadi kunci dalam pengembangan pasar keuangan karena memengaruhi tingkat risiko dan pengembalian (risk-return), yang pada gilirannya menjadi daya tarik bagi investor domestik maupun asing. Pasar obligasi pemerintah yang likuid mendukung pengembangan pasar keuangan karena seri benchmark yang diterbitkan pemerintah menjadi acuan bagi penerbitan obligasi oleh korporasi. Untuk menjadi seri benchmark yang dapat diandalkan dan berfungsi efektif memberikan sinyal harga (price signal) kepada para pelaku pasar, dibutuhkan likuiditas bahkan dalam kondisi pasar sedang mengalami tekanan. Dengan kata lain, pasar sekunder yang aktif akan mendorong terjadinya likuiditas dan proses pembentukan harga di pasar. Lebih lanjut sebagaimana argumen Blommestein (2017), terbentuknya likuiditas pasar sekunder bergantung pada beberapa aspek microstructure, seperti penerbitan seri-seri benchmark secara konsisten dan berkesinambungan, pasar spot dan repo yang berfungsi dengan baik, kemampuan untuk melakukan short sell, keberadaan pasar derivatif, dan otomasi serta struktur pasar elektronik. Karena likuiditas pasar obligasi pemerintah memengaruhi secara langsung peluang funding dan financing costs, likuiditas pasar dan funding pemerintah menjadi sangat erat keterkaitannya.

Mohanty (2002) termasuk yang berpendapat bahwa pemerintah harus proaktif melakukan langkah yang diperlukan untuk mendorong terciptanya likuiditas di pasar. Contoh untuk di pasar perdana, seperti mengimplementasikan issuance techniques yang menciptakan persaingan serta mendorong price discovery. Contoh di pasar sekunder misalnya mengembangkan repo market. Rendahnya likuiditas dapat diakibatkan kurang dalamnya pasar 
(market depth). Menurut Mohanty (2002), pemerintah (bank sentral maupun treasury) dapat memberlakukan kebijakan untuk mendorong pendalaman pasar serta peran market microstructure dalam mendorong likuiditas pasar obligasi melalui pasar repo, securities lending e borrowing, penerbitan seri benchmark, serta mark to market.

Dalam hal pasar Sukuk, terdapat beberapa perbedaan dalam menciptakan market microstructure agar tidak bertentangan dengan prinsip syariah. Pasar repo Sukuk baru ada ketika Bank Indonesia menerbitkan peraturan mengenai pasar uang antar bank berdasarkan prinsip syariah tahun 2015 (Peraturan Bank Indonesia No. 17/4/PBI/2015). Dengan peraturan tersebut, Bank Indonesia berupaya menambah alternatif instrumen likuiditas bagi bank syariah melalui transaksi repo (repurchase agreement). Adapun mark to market Sukuk, sebelum revisi PSAK 110 tentang Akuntansi Sukuk tahun 2015, investor hanya diperbolehkan mencatat investasi Sukuk pada buku trading dan hold to maturity (HTM). Hal tersebut mempengaruhi minat beli dan persepsi risiko investor terhadap sukuk.

\subsection{Likuiditas}

Faktor likuiditas dapat mempengaruhi harga obligasi. Amihud \& Mendelson (1991) melakukan penelitian mengenai likuiditas obligasi Pemerintah di pasar obligasi Amerika Serikat dengan membandingkan antara jenis T-Notes dan T-Bills. Kesimpulan dari penelitian tersebut memperlihatkan bahwa likuiditas mempengaruhi harga obligasi karena investor membutuhkan kompensasi atas biaya transaksi. Beberapa sumber illiquidity sebagaimana dieksplorasi oleh Amihud et al., (2005) yaitu exogenous transaction costs seperti brokerage fees, order-processing costs, dan transaction taxes; demand pressure; inventory risk; dan difficulty of locating a counterparty. Biaya likuiditas tersebut akan mempengaruhi harga obligasi karena investor meminta kompensasi atas risiko yang harus mereka tanggung.

Menurut Kyle (1985), dimensi likuiditas terdiri dari tiga yaitu tightness, depth, dan resiliency. Pastor \& Stambaugh (2003) menganalisis bahwa likuiditas merupakan faktor yang paling penting bagi investor dalam menentukan harga saham, dan pengaruh risiko likuiditas tersebut juga signifikan berdampak terhadap instrumen pasar keuangan lain seperti fixed income securities. Dalam obligasi, Elton et al (2001) menguji faktor yang mempengaruhi spread corporate bonds terhadap treasury bonds. Kesimpulannya adalah risiko likuiditas berpengaruh signifikan terhadap spread antara corporate bonds dan treasury bonds selain default risk dan perbedaan perlakuan perpajakan. Temuan lebih spesifik dihasilkan dari Black et al. (2014) yang meneliti tentang komponen bond yield spreads (selain faktor default) untuk menentukan mana dari ketiga dimensi tersebut yang penting bagi investor. Hasilnya, faktor terpenting adalah cost dimension, diikuti oleh time dan selanjutnya depth.

Dalam penelitian terhadap non-default spread (NDS), Black et al. (2015) menemukan bahwa faktor trading cost dan resiliency lebih penting daripada depth. Investor juga memperhitungkan faktor bond-specific dan market-wide dimensions of liquidity dalam menentukan harga. Black et al. (2015) meneliti tentang hubungan dari masing-masing dimensi likuiditas (trading cost, depth, dan resiliency) terhadap keputusan investor dalam menentukan harga obligasi yang dijamin Pemerintah Amerika (guaranted bonds). Penelitian tersebut menggunakan variabel dependen berupa spread return (yield) obligasi korporasi yang dijamin Pemerintah Amerika (guaranted bonds) terhadap US Treasury (UST) yang kemudian disebut sebagai non-default spread (NDS), mengingat kedua instrumen tersebut memiliki risiko default yang sama dan perlakuan perpajakan yang sama namun investor memberi perlakuan berbeda dalam menentukan pricing. Dalam kasus ini, Black et al. (2015) berpendapat bahwa faktor yang menyebabkan investor memberikan premium bagi yield guaranted bonds terhadap UST adalah risiko likuiditas. Hasilnya, ketiga dimensi likuiditas tersebut berpengaruh signifikan terhadap spread guaranted bonds terhadap UST.

Untuk penelitian likuiditas sukuk telah dilakukan penelitian oleh beberapa peneliti di antaranya adalah Arif, Chazi, et al. (2017) yang meneliti tentang perbedaan yield sukuk dan 
obligasi konvensional di Malaysia. Dalam penelitiannya disimpulkan bahwa sukuk secara ratarata memiliki yield lebih tinggi dibandingkan obligasi dengan rentang 8-25 bps dan melebar seiring bertambahnya tenor sukuk. Dalam penelitiannya, pergerakan selisih lebih tersebut sejalan dengan teori liquidity premium, yaitu semakin tidak likuid suatu instrumen investor menambahkan premi atas faktor likuiditas tersebut. Selain itu, Karatas (2019) meneliti tentang persepsi investor sukuk negara Malaysia, Turki, Indonesia, dan Hongkong yang diterbitkan di pasar internasional. Dalam penelitian ini dianalisis mengenai apakah sukuk merupakan kelas aset yang berbeda dengan membandingkan yield sukuk dan obligasi di negara Malaysia, Indonesia, Turki, dan Hongkong. Kesimpulannya, di beberapa negara tersebut, Sukuk tidak dinilai sebagai kelas aset yang berbeda dan jika terjadi perbedaan harga antara obligasi dan sukuk lebih dikarenakan perilaku investor Sukuk yang cenderung hold to maturity (dimiliki sampai dengan jatuh tempo).

Di Indonesia penelitian tentang likuiditas Sukuk Negara (SBSN) telah dilakukan pula di antaranya adalah Nurhasanah (2011) yang meneliti pengaruh faktor likuiditas terhadap harga sukuk. Penelitian ini menggunakan frekuensi dan volume perdagangan sebagai variabel likuiditas. Berdasarkan penelitiannya, faktor likuiditas tidak berpengaruh signifikan terhadap harga Sukuk Negara, tetap faktor lain seperti kupon dan maturity berpengaruh signifikan terhadap harga Sukuk Negara. Penelitian lainnya dilakukan oleh Rifaldi (2014) yang meneliti mengenai faktor-faktor yang mempengruhi harga Sukuk Negara seri Project Based Sukuk (PBS) di pasar sekunder. Penelitian ini menggunakan variabel frekuensi perdagangan, volume perdagangan, kupon, dan maturity untuk mengukur pengaruhnya terhadap harga Sukuk Negara seri PBS di pasar sekunder. Dalam penelitian ini disumpulkan bahwa frekuensi, volume perdagangan, kupon, dan time to maturity berpengaruh signifikan terhadap harga SBSN seri PBS.

Penelitian lain yang menggunakan dimensi likuiditas telah digunakan pula dalam penelitian Bunaidy (2012). Penelitian ini menggunakan metode analisis deskriptif dimensi likuiditas Obligasi Negara termasuk Sukuk Negara. Dimensi yang digunakan dalam penelitian ini adalah dimensi trading cost yang diukur dengan bid-ask spread melalui roll measure dan dimensi market depth yang diukur dengan amihud measure dan amivest measure.

\subsection{Dimensi Likuiditas dalam Menentukan Liquidity Premium}

Dick-nielsen et al., (2012) melakukan penelitian tentang komponen likuiditas dari spread obligasi korporasi dan US Treasury. Untuk mengukurnya Dick-nielsen et al. (2012) menggunakan amihud measure (price impact of trades), roll measure (bid-ask spread), imputed roundtrip cost (bid-ask spread), dan turnover (trading intensity). Amihud measure merupakan model pengukuran yang dikembangkan oleh Amihud berdasarkan model teoritis Kyle (1985). Model tersebut mengukur dampak harga per unit yang diperdagangkan. Aset yang likuid dapat dibeli atau dijual dengan rentang harga yang tidak terlalu jauh dari harga fundamentalnya mencerminkan bahwa roundtrip cost-nya rendah. Bid-ask spread digunakan sebagai proxi roundtrip cost tersebut (roll measure). Alternatif pengukuran roundtrip cost tersebut (bid-ask spread), sebagaimana ditawarkan Feldh"utter (2010) dalam Dick-nielsen et al., (2012), adalah dengan menggunakan unique roundtrip trades (URT). Selanjutnya, turnover (trading intensity) dihitung dari perbandingan antara total trading amount dan jumlah outstanding per kuartal. Aset yang diperdagangkan secara berkala secara intuitif lebih likuid dibandingkan aset yang jarang diperdagangkan.

Black et al. (2015) yang meneliti non-default spread (NDS) menggunakan dimensi likuiditas trading cost yang digambarkan melalui bid-ask spread, dimensi market depth yang digambarkan dengan amihud measure dan dimensi resiliency yang digambarkan dengan beta dari perubahan kepemilikan dealer. Untuk pengukuran dimensi trading cost Black et al. (2015) mengikuti Hong \& Warga (2000) dan memperkirakan bid-ask spread harian untuk setiap obligasi dengan menghitung selisih antara volume rata-rata tertimbang harian harga beli dan harga jual. Untuk dimensi market depth, dilakukan pendekatan yang sama dengan Dick-nielsen et al. (2012) yaitu 
menggunakan amihud illiquidity measure sebagai proxi price impact of trades. Sedangkan untuk pengukuran resiliency, Black et al. (2015) menggunakan kerangka seberapa lama distorsi terhadap likuiditas - yang dapat dilihat dari dimensi trading cost atau market depth - kembali ke posisi semula. Perubahan agregate kepemilikan dealer mencerminkan keseluruhan pesanan (order) di pasar sehingga digunakan beta perubahan kepemilikan dealer sebagai pengukuran resiliency dimension.

\section{METODE PENELITIAN}

Penelitian ini menggunakan metode kuantitatif, yaitu model dinamis untuk mengidentifikasi faktor-faktor yang mempengaruhi premi likuiditas di pasar sukuk. Metode tersebut digunakan untuk menguji hipotesis yaitu menguji hubungan antar variabel yang merupakan dimensi likuiditas. Model yang dihasilkan diharapkan dapat menjelaskan pengaruh antara dimensi trading cost dan market depth terhadap liquidity premium yang diminta investor dengan menggunakan data sekunder dari perdagangan harian yang dilaporkan melalui Laporan Transaksi OTC Bursa Efek Indonesia.

Sampel dari penelitian ini adalah data bulanan Sukuk Negara seri PBS yang terdiri dari PBS003 yang jatuh tempo pada tanggal 15 Januari 2027, kupon 6\% dan volume per Desember 2016 sebesar Rp3,786 triliun serta seri PBS004 yang jatuh tempo pada tanggal 15 Februari 2037, kupon 6,1\% dan volum per Desember 2016 sebesar Rp10,149 triliun. Periode penelitian adalah Januari 2012 - Desember 2016. Pemilihan sampel dilakukan dengan tahap sebagai berikut:

1. Menentukan seri-seri Sukuk Negara atau SBSN yang memiliki kesamaan jatuh tempo atau memiliki jatuh tempo di tahun yang sama dengan seri-seri SUN dengan melihat outstanding Sukuk Negara dan SUN pada periode 2012-2016 yang diperoleh dari Kementerian Keuangan. Seri-seri dengan TTM yang sama dapat dilihat pada Tabel 2.

TABEL-2: Perbandingan seri-seri Sukuk Negara dan SUN

\begin{tabular}{|c|c|c|c|c|c|c|c|}
\hline \multicolumn{4}{|c|}{ SBSN } & \multicolumn{4}{|c|}{ SUN } \\
\hline Series & First Issue Date & Maturity & Coupon & Series & First Issue Date & Maturity & Coupon \\
\hline IFR0002 & 26-Aug-08 & 15-Aug-18 & $11.95 \%$ & FR0038 & 24-Aug-06 & 15-Aug-18 & $11.60 \%$ \\
\hline IFR0006 & 1-Apr-10 & 15-Mar-30 & $10.25 \%$ & FR0052 & 20-Aug-09 & 15-Aug-30 & $10.50 \%$ \\
\hline \begin{tabular}{|l|} 
IFR0007 \\
\end{tabular} & 21-Jan-10 & 15-Jan-25 & $10.25 \%$ & FR0040 & 21-Sep-06 & 15-Sep-25 & $11.00 \%$ \\
\hline IFR0010 & 3-Mar-11 & 15-Feb-36 & $10 \%$ & FR0072 & 9-Jul-15 & 15-May-36 & $8.25 \%$ \\
\hline PBS001 & 16-Feb-12 & 15-Feb-18 & $4.45 \%$ & FR0032 & 1-Sep-05 & 15-Jul-18 & $15 \%$ \\
\hline PBS002 & 15-Jan-22 & 15-Jan-22 & $5.45 \%$ & FR0061 & 6-Oct-11 & 15-May-22 & $7.00 \%$ \\
\hline PBSO03 & 2-Feb-12 & 15-Jan-27 & $6.00 \%$ & FR0059 & 15-Sep-11 & 15-May-27 & $7.00 \%$ \\
\hline \begin{tabular}{|l|} 
PBSO04 \\
\end{tabular} & 16-Feb-12 & 15-Feb-37 & $6.10 \%$ & FR0045 & 24-May-07 & 15-May-37 & $9.75 \%$ \\
\hline PBS006 & 19-Sep-13 & 15-Sep-20 & $8.25 \%$ & FR0031 & 16-Jun-05 & $15-$ Nov-20 & $11.00 \%$ \\
\hline PBS009 & $30-\mathrm{Jul}-15$ & 25-Jan-18 & $7.75 \%$ & FR0066 & 25-Oct-12 & 15-May-18 & $5.25 \%$ \\
\hline \begin{tabular}{|l|} 
PBS011 \\
\end{tabular} & 14-Jan-16 & 15-Aug-23 & $8.75 \%$ & FR0039 & 24-Aug-06 & 15-Aug-23 & $11.75 \%$ \\
\hline PBS012 & 28-Jan-16 & 15-Nov-31 & $8.88 \%$ & FR0054 & 22-Jul-10 & 15-Jul-31 & $9.50 \%$ \\
\hline \begin{tabular}{|l|} 
PBS013 \\
\end{tabular} & 6-Oct-16 & 15-May-19 & $6.25 \%$ & FR0069 & 29-Aug-13 & 15-Apr-19 & $7.88 \%$ \\
\hline PBS014 & 6-Oct-16 & 15-Мay-21 & $6.50 \%$ & FR0034 & 26-Jan-06 & 15-Jun-21 & $12.80 \%$ \\
\hline
\end{tabular}

Catatan: Dari DJPPR, Kementerian Keuangan (2017).

2. Memilih sampel yang menggambarkan kondisi selama periode penelitian, dengan tahapan sebagai berikut:

a. Dari Tabel 2 peneliti menghilangkan SBSN seri IFR karena sejak 2012 Pemerintah tidak lagi menerbitkan seri IFR. Sejak itu dan hingga saat ini Pemerintah secara regular menerbitkan SBSN seri PBS.

b. Memilih SBSN seri PBS dengan waktu penerbitan yang tidak jauh berbeda (pada bulan yang sama karena sampel akan dirata-rata bulanan).

c. Memilih SBSN dengan TTM yang panjang, sehingga hasil penelitian masih dapat dijadikan salah satu refensi bagi penerbit jika akan melakukan penerbitan kembali seri yang sama (reopening). 
d. Seri SUN pembanding adalah seri yang aktif diperdagangkan di pasar sekunder.

Dari kedua tahapan di atas, maka data bulanan Sukuk Negara seri PBS003 dan PBSO04 periode Januari 2012 - Desember 2016 dipilih sebagai obyek observasi.

Model regresi yang digunakan pada studi ini mengacu pada model yang digunakan pada studi yang dilakukan oleh Black, et al. (2016) yang meneliti tentang hubungan dari masingmasing dimensi likuiditas (trading cost, depth, dan resiliency) terhadap keputusan investor dalam menetapkan harga (pricing) obligasi yang dijamin Pemerintah Amerika (guaranted bonds). Penelitian ini menggunakan variabel dependent berupa spread return (yield) obligasi korporasi yang dijamin Pemerintah Amerika (guaranted bonds) terhadap US Treasury (UST) yang kemudian disebut sebagai Non-Default Spread (NDS), mengingat kedua instrumen tersebut memiliki risiko default yang sama dan perlakuan perpajakan yang sama, tetapi investor berbeda dalam memberikan pricing. Model yang digunakan yaitu:

$$
N D S_{i d}=\alpha+\beta_{1} \ln (\text { spread })_{i d}+\beta_{2} \ln (\text { Amihud })_{i d}+\beta_{3}\left(-\ln (\text { resil })_{i d}+\beta^{\prime} X+\varepsilon_{i d}\right.
$$

Dimana:

$$
\begin{array}{ll}
\text { NDS } & \text { = Non-Default Spread } \\
\text { Spread } & =\text { bid-ask spread mewakili dimensi trading cost } \\
\text { Amihud } & =\text { Amihud Measure (Amihud, 2002) yang mewakili dimensi market depth } \\
\text { Resil } & =\text { slope dari perubahan kepemilikan dealer mewakili dimensi resiliency }
\end{array}
$$

Adapun variabel dalam penelitian ini dapat diuraikan sebagai berikut:

1. Spread yield Sukuk Negara seri PBS003 dan PBS004 terhadap SUN dengan TTM di tahun yang sama $(\underline{\text { prem }} \dot{i})$. Dalam menentukan spread yield Sukuk Negara dan SUN dilakukan dengan cara mencari rata-rata harian dari masing-masing seri kemudian diselisihkan dengan formula berikut:

$$
\text { prem }_{i}=\text { average yield } S B S N_{i}-\text { average yield } S U N_{i}
$$

2. Trading Cost.

Untuk mengukur trading cost menggunakan data Laporan Transaksi OTC Bursa Efek Indonesia. Nilai bid-ask spread diperoleh dengan menggunakan formula yang digunakan Black et al. (2015):

$$
\operatorname{spread}_{d}=\frac{\frac{\sum_{D=1} q_{i d} p_{i d}}{\sum_{D=1} q_{i d}}-\frac{\sum_{D=-1} q_{i d} p_{i d}}{\sum_{D=-1} q_{i d}}}{\left(\frac{\sum_{D=1} q_{i d} p_{i d}}{\sum_{D=1} q_{i d}}+\frac{\sum_{D=-1} q_{i d} p_{i d}}{\sum_{D=-1} q_{i d}}\right)}
$$

Dimana quadalah volume perdagangan $D=1$ pada transaksi i di hari d, $\underline{p_{i d}} \underline{D=1 \text { adalah }} \begin{gathered}\text { perdagangan } \\ \text { adalah harga }\end{gathered}$ pada transaksi i di hari d, ask price dan adalah bid price.

3. Market Depth.

Untuk mengukur kedalaman pasar digunakan pengukuran yang digunakan dalam penelitian Dick-nielsen et al. (2012) dengan formula sebagai berikut:

$$
\text { Amihud }_{d}=\frac{1}{N_{d}} \sum_{d=1}^{N_{d}} \frac{\left|\frac{s_{t}-s_{t-1}}{s_{t-1}}\right|}{Q_{t}}
$$


Dimana N dalah jumlah perdagangan dari Sukuk Negara pada hari d, s adalah harga Sukuk Negara dan Q adalah nominal Sukuk Negara yang diperdagangkan.

4. Dalam penelitian ini digunakan variabel kontrol berupa kupon dan TTM.

Kupon (imbalan) SBSN dalam penelitian ini adalah present value dari kupon yang akan diterima sampai dengan jatuh tempo. TTM adalah sisa umur Sukuk Negara dari tanggal observasi sampai dengan tanggal jatuh tempo.

\section{HASIL ANALISIS DAN PEMBAHASAN}

\subsection{Sukuk Negara dan SUN}

Pengaruh dimensi likuiditas terhadap yield spread Sukuk Negara seri PBS003 sebagaimana diperlihatkan pada Tabel 3. Hasil regresi menunjukkan bahwa liquidity premium (PREM_PBS003) dipengaruhi oleh variabel-variabel seperti liquidity premium 6 bulan sebelumnya (PREM_PBSO03(-6)), bid-ask spread 5 bulan (SPREAD_PBSO03(-5)) dan 3 bulan sebelumnya (SPREAD_PBSO03(-3)), kupon (KUPON_PBSO03) dan TTM 2 bulan sebelumnya (TTM_PBSO03(-2)). Lag dari setiap variabel independen tersebut ditentukan berdasarkan signifikansi dari uji t-stat, R-Square, Akaike info Criterion dan schwarz criterion. Dalam persamaan $\mathrm{PBSO03}$ variabel amihud tidak signifikan mempengaruhi liquidity premium PBSO03.

TABLE 3: Hasil regresi Sukuk Negara seri PBS003

\begin{tabular}{lrcrc}
\hline \hline \multicolumn{1}{c}{ Variable } & Coefficient & Std. Error & t-Statistic & Prob. \\
\hline \hline \multicolumn{1}{c}{ C } & -0.059935 & 0.023353 & -2.566432 & 0.0136 \\
D(PREM_PBS03(-6)) & 0.304035 & 0.105967 & 2.869156 & 0.0062 \\
D(SPREAD_PBS03(-3)) & 0.007958 & 0.002048 & 3.885632 & 0.0003 \\
D(SPREAD_PBS03(-5)) & -0.005641 & 0.001901 & -2.967512 & 0.0048 \\
D(KUPON_PBS03) & -0.122290 & 0.033472 & -3.653468 & 0.0007 \\
D(TTM_PBS03(-2)) & -0.717884 & 0.280193 & -2.562102 & 0.0137 \\
\hline \hline R-squared & 0.520202 & Mean dependent var & 0.000129 \\
Adjusted R-squared & 0.468050 & S.D. dependent var & 0.005903 \\
S.E. of regression & 0.004306 & Akaike info criterion & -7.949604 \\
Sum squared resid & 0.000853 & Schwarz criterion & -7.724461 \\
Log likelihood & 212.6897 & Hannan-Quinn criter. & -7.863290 \\
F-statistic & 9.974726 & Durbin-Watson stat & 2.257002 \\
Prob(F-statistic) & 0.000002 & & & \\
\hline \hline
\end{tabular}

Persamaan model yang dihasilkan adalah sebagai berikut:

$$
\begin{aligned}
\Delta \text { prem }_{\mathrm{t}} & =-0,059935+0,304035 \Delta(\text { prem })_{\mathrm{t}-6} \\
& +0,007958 \Delta(\text { spread })_{\mathrm{t}-3} \\
& -0,005641 \Delta(\text { spread })_{\mathrm{t}-5} \\
& -0.122290 \Delta(\text { kupon })_{\mathrm{t}} \\
& -0,717884 \Delta(\mathrm{ttm})_{\mathrm{t}-2}+\varepsilon
\end{aligned}
$$

Dari hasil persamaan tersebut dapat disimpulkan bahwa jika variabel liquidity premium 6 bulan sebelumnya, bid-ask spread 3 bulan sebelumnya, bid-ask spread 5 bulan sebelumnya, kupon dan TTM 2 bulan sebelumnya bernilai nol, maka liquidity premium Sukuk Negara seri PBS003 akan berubah sebesar -5,99\%. Hal tersebut dapat dipahami, mengingat instrumen PBS003 adalah instrumen yang tidak banyak diperdagangkan di pasar sekunder sehingga sebagian besar disimpan investor sampai jatuh tempo. Hal ini terlihat dari rata-rata turnover harian PBS003 yang hanya sebesar 0,02784 kali. 
Koefisien korelasi liquidity premium t-6 sebesar 0,304035 menunjukkan investor cenderung menambahkan premi sebesar 30\% terhadap liquidity premium 6 bulan sebelumnya mengingat PBS003 tidak banyak ditransaksikan di pasar sekunder sehingga investor melihat liquidity premium pada transaksi sebelumnya dimana dalam penelitian ini yaitu 6 bulan sebelumnya.

Koefisien korelasi dimensi trading cost $\mathrm{t}-3$ sebesar 0,007958 dan $\mathrm{t}-5$ sebesar $-0,005641$. Hal ini menandakan bahwa investor dalam jangka panjang berharap adanya volatilitas dari PBS003, tetapi dalam jangka pendek investor lebih memperhatikan likuiditas dalam mengukur risiko PBS003. Dalam jangka panjang obligasi lebih sensitif terhadap perubahan suku bunga (Fabozzi, 2000), maka dalam hal ini sukuk bertenor panjang seperti PBS003 dan PBS004 lebih sensitif terhadap perubahan suku bunga, sehingga volatilitas semakin besar jika sukuk dipegang dalam jangka panjang.

Variabel kupon memiliki koefisien korelasi sebesar -12,22\% yang telah sesuai dengan teori bahwa untuk instrumen yang memiliki cashflow tetap, jika present value cashflow naik maka risiko terhadap instrumen keuangan tersebut akan turun (Fabozzi, 2000).

Koefisien korelasi TTM t-2 sebesar -0,717884. Hal ini mengingat PBS003 tidak banyak ditransaksikan sehingga turunnya TTM tidak disertai dengan turunnya yield. Kondisi tersebut ditambah dengan naiknya BI Rate sebagai suku bunga acuan sejak pertengahan tahun 2013 sampai dengan awal tahun 2016, sehingga saat TTM berkurang yield PBS003 tidak mengalami penurunan bahkan cenderung naik.

GAMBAR-1: BI Rate periode 2012 s.d. 2016

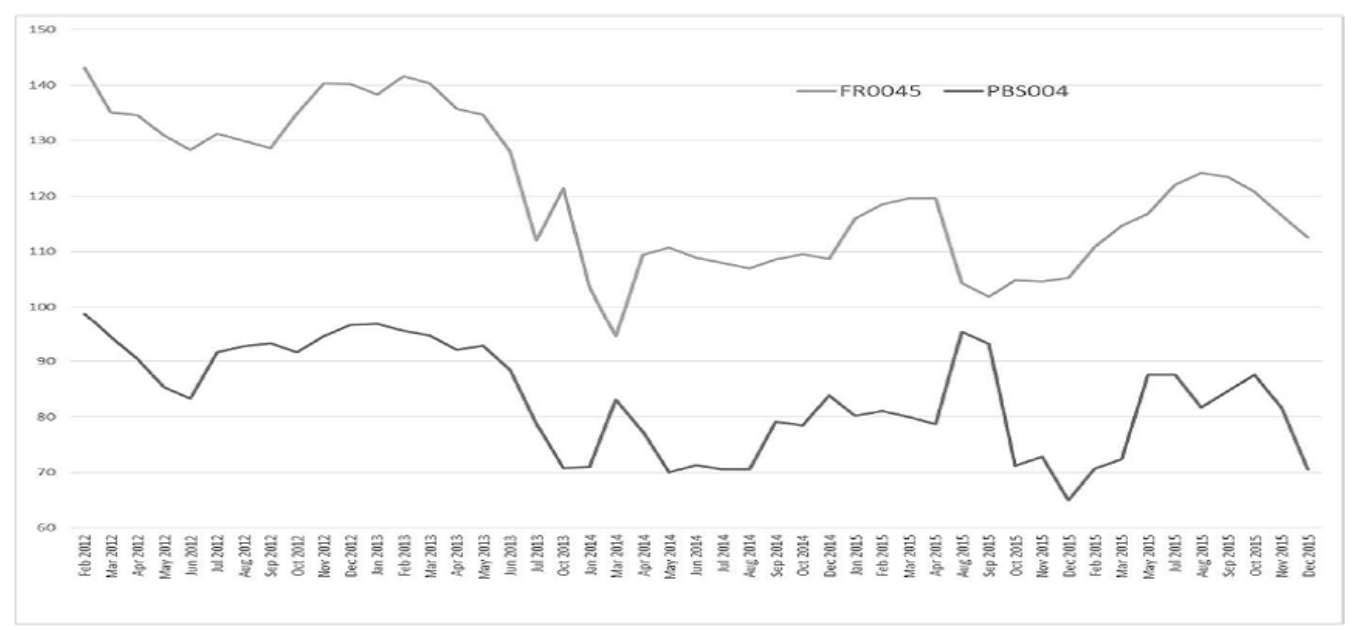

Catatan: Dari Bank Indonesia (2017), diolah.

Dimensi market depth t-4 mempengaruhi signifikan pada PBS004 dengan koefisien korelasi sebesar 0,049530. Penyebab signifikansi Amihud pada t-4 antara lain disebabkan terdapat lag informasi harga wajar karena tidak adanya kuotasi yang dilakukan oleh Primary Dealers.

Terkait dengan lag pada variabel TTM yaitu $\mathrm{t}-3$ diduga karena ekspektasi investor terhadap liquidity premium dipengaruhi oleh kebutuhan investor untuk wajib menjual dalam waktu 90 hari (3 bulan) sebagai dampak dari PSAK 110 tentang investasi sukuk yang hanya dapat dicatat di dua buku yaitu trading book dan hold to maturity. Namun, PBS004 termasuk instrumen yang likuid, maka turunnya TTM akan menurunkan risiko sukuk sesuai dengan teori.

\subsection{Analisis Ekonomi}

Secara umum penerbitan Sukuk Negara meningkat dibandingkan dengan periode awal penerbitan sebagaimana dapat dilihat pada Gambar 3. Melalui penerbitan seri PBS, pemerintah melakukan inovasi dalam underlying asset, dari sebelumnya mengandalkan Barang Milik Negara (BMN), menjadi penerbitan sukuk untuk membiayai proyek APBN. Pergantian sumber 
utama underlying asset tersebut memberikan dampak yang cukup signifikan dalam penerbitan Sukuk Negara, dimana sejak tahun 2012 penerbitan Sukuk Negara meningkat jumlahnya, khususnya untuk seri PBS.

GAMBAR-3: Penerbitan Sukuk Negara periode 2008 - 2017

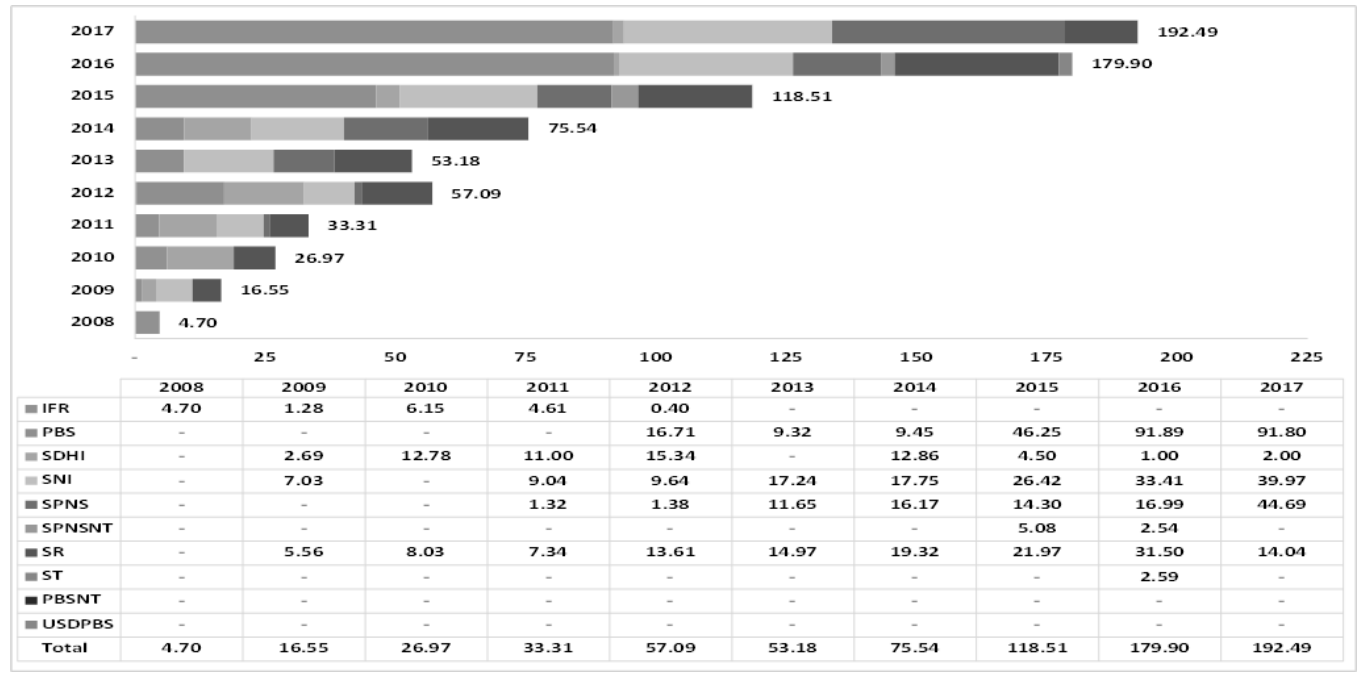

Catatan: Dari Direktorat Pembiayaan Syariah, DJPPR, Kementerian Keuangan (2017).

Selain itu, pada periode observasi ada beberapa kondisi infrastruktur pasar yang berbeda antara SUN dan Sukuk Negara yang cukup mempengaruhi persepsi tingkat risiko terhadap kedua instrumen tersebut, yaitu:

1. Instrumen SUN memiliki market maker yang disebut Dealer Utama SUN. Dealer Utama SUN memiliki kewajiban menyampaikan penawaran pembelian pada setiap Lelang SUN di pasar perdana domestik; memenangkan paling kurang 2,00\% dari total indikatif penerbitan SUN yang dimenangkan saat Lelang SUN dalam rentang waktu 3 bulan; melaksanakan perdagangan SUN dalam mata uang rupiah sekurang-kurangnya 2,00\% dari total volume transaksi SUN Seri Benchmark dalam mata uang rupiah dalam rentang waktu 3 bulan. Selain itu kewajiban lainnya meliputi melakukan kuotasi harga SUN seri benchmark dua arah (two-way prices) setiap hari kerja selama satu tahun yang siap dieksekusi, kuotasi harga indikatif, dan kewajiban kuotasi dua arah. Sedangkan pasar Sukuk Negara tidak memiliki market maker. Terdapat Peserta Lelang SBSN dengan kewajiban melakukan bids di pasar perdana, tanpa ada kewajiban di pasar sekunder.

2. Belum tersedianya infrastruktur pasar keuangan syariah yang memadai. Pelaksanaan repo syariah diberlakukan sejak April 2015, tetapi berbeda perlakuan dengan repo konvensional. Repo syariah hanya dapat dilakukan jika terdapat penjualan haqiqi sejak 1st lag. Sedangkan, pada repo konvensional penjualan haqiqi dapat dilakukan pada 2-nd lag.

3. Perbedaan perlakuan pencatatan akuntansi sukuk dan obligasi. Pada PSAK 50 tentang instrumen keuangan mengatur bahwa obligasi dapat dicatat pada trading book, available for sale (AFS) dan hold to maturity (HTM). Namun, PSAK 110 tentang investasi sukuk hanya memperbolehkan pencatatan instrumen sukuk pada trading book dan HTM (kemudian diubah pada tanggal 25 Februari 2015 dengan memperbolehkan sukuk dicatat pada tiga buku, termasuk Available for Sale).

Penentuan liquidity premium oleh investor tergantung dari karakteristik masing-masing seri Sukuk Negara dan seri SUN pembanding. Hal ini sejalan dengan riset yang dilakukan oleh Direktorat Pembiayaan Syariah (2017) yang tidak dipublikasikan, yaitu investor sangat memperhatikan harga SUN dengan tenor yang sama dalam menentukan harga Sukuk Negara. Dalam penelitian ini dari sampel diketahui bahwa jika seri SUN dengan tenor sama adalah seri benchmark, maka PBS cenderung tidak likuid sehingga dimensi market depth tidak 
berpengaruh signifikan terhadap penentuan liquidity premium Sukuk Negara. Namun, sebaliknya jika seri PBS aktif diterbitkan oleh Pemerintah dan seri SUN dengan tenor sama bukan merupakan seri benchmark, maka seri PBS lebih likuid dibandingkan dengan seri SUN yang dibuktikan dengan dimensi trading cost dan dimensi market depth berpengaruh signifikan terhadap premi risiko SBSN.

Selanjutnya, karena seri PBS dibeli oleh korporasi, maka jenis industri yang membeli Sukuk Negara tersebut mempengaruhi besaran liquidity premium. Hal tersebut karena beberapa industri seperti Dana Pensiun dan Asuransi tidak mempertimbangkan likuiditas dalam membeli Sukuk Negara. Mereka lebih mempertimbangkan kupon, TTM, serta target return internal perusahaan dalam melakukan pembelian instrumen keuangan. Pada Tabel 3 dapat dilihat bahwa kepemilikan Sukuk Negara seri PBS003 sebanyak 76\% dimiliki oleh Asuransi dan Dana Pensiun. Sementara itu, seri PBS004, sekalipun sebanyak 68\% dimiliki oleh Asuransi dan Dana Pensiun, kepemilikan bank khususnya bank syariah dan reksadana memiliki porsi yang cukup besar. Diduga kedua jenis industri tersebut (perbankan dan manajemen aset) yang menggerakkan pasar sekunder PBS004. Komposisi kepemilikan PBS003 dan PBSO04 dapat dilihat pada Tabel 3.

TABEL-3: Kepemilikan PBS003 dan PBSO04

\begin{tabular}{|l|r|r|r|r|}
\hline \multirow{2}{*}{ Industri } & \multicolumn{2}{|c|}{ PBSO03 } & \multicolumn{2}{c|}{ PBS004 } \\
\cline { 2 - 5 } & $\begin{array}{c}\text { Nominal } \\
\text { (miliar rupiah) }\end{array}$ & \multicolumn{1}{c|}{$\%$} & $\begin{array}{c}\text { Nominal } \\
\text { (miliar rupiah) }\end{array}$ & \multicolumn{1}{c|}{$\%$} \\
\hline Bank Konvensional & 511.82 & $13.52 \%$ & 315.00 & $3.10 \%$ \\
\hline Bank Syariah & 128.43 & $3.39 \%$ & $1,756.64$ & $17.31 \%$ \\
\hline Bank Indonesia & - & $0.00 \%$ & - & $0.00 \%$ \\
\hline Institusi Lainnya & - & $0.00 \%$ & - & $0.00 \%$ \\
\hline - Asuransi & $2,762.45$ & $72.96 \%$ & $5,131.75$ & $50.56 \%$ \\
\hline - Dana Pensiun & 135.00 & $3.57 \%$ & $1,773.44$ & $17.47 \%$ \\
\hline - Korporasi & 17.53 & $0.46 \%$ & 5.00 & $0.05 \%$ \\
\hline - Perorangan & 5.00 & $0.13 \%$ & 89.00 & $0.88 \%$ \\
\hline - Sekuritas & - & $0.00 \%$ & - & $0.00 \%$ \\
\hline - Reksadana & 130.78 & $3.45 \%$ & 621.59 & $6.12 \%$ \\
\hline - Lainnya & 20.00 & $0.53 \%$ & 456.59 & $4.50 \%$ \\
\hline Asing & 75.00 & $1.98 \%$ & - & $0.00 \%$ \\
\hline TOTAL & $3,786.00$ & & $10,149.00$ & \\
\hline
\end{tabular}

*) data per 31 Desember 2015

Catatan: Dari Direktorat Pembiayaan Syariah, DJPPR, Kementerian Keuangan (2016), diolah.

Perilaku investor (investor behavior) juga mempengaruhi besaran liquidity premium. Investor cenderung mencari instrumen yang lebih mudah untuk dijual atau dijaminkan saat membutuhkan likuiditas. jika membutuhkan likuiditas, investor cenderung menjual SUN yang dimiliki dibandingkan menjual Sukuk Negara karena harga SUN secara rata-rata lebih tinggi dibandingkan Sukuk Negara.

Dari hasil penelitian diduga terdapat kecenderungan dari investor melakukan praktek arbitrage, yaitu jual beli aset untuk mendapatkan keuntungan dari perbedaan harga instrumen keuangan yang identik, berbeda pasar, atau berbeda bentuk. Hal tersebut dilakukan karena selisih harga yang cukup lebar antara PBS004 dan FR0045. Perbedaan imbalan (kupon) yang cukup besar dimana PBS004 memberikan kupon sebesar 6,1\%, sedangkan FR0045 sebesar 9\%, menyebabkan pada tingkat yield yang sama akan memberikan harga yang berbeda. Perbedaan tersebut dimanfaatkan oleh pelaku pasar untuk mendapatkan keuntungan dengan memperdagangkan PBS004. Sehingga pada waktu tertentu yield PBS004 lebih rendah dibandingkan dengan yield FR0045, tetapi harga PBS004 tetap lebih rendah dibandingkan dengan FR0045. 


\section{KESIMPULAN}

Dari hasil penelitian ini dapat disimpulkan bahwa likuiditas merupakan faktor yang signifikan mempengaruhi liquidity premium Sukuk Negara terhadap SUN, tetapi bukan menjadi faktor yang sangat dominan. Dari hasil penelitian diperoleh bahwa dimensi trading cost berpengaruh signifikan terhadap liquidity premium PBS003 dan PBS004, tapi untuk sampel PBS003 trading cost 5 bulan sebelumnya dan 3 bulan sebelumnya signifikan terhadap liquidity premium PBS003. Hal ini menunjukkan bahwa PBS003 bukan merupakan instrumen yang aktif diperdagangkan. Selain itu, terdapat perbedaan arah koefisien korelasi antara trading cost $\mathrm{t}-3$ dan trading cost $\mathrm{t}-5$, dalam hal ini trading cost $\mathrm{t}-5$ koefisien korelasi bertanda negatif. Hal tersebut menunjukkan bahwa investor dalam jangka panjang berharap adanya volatilitas dari PBS003, tetapi dalam jangka pendek investor lebih memperhatikan likuiditas dalam mengukur risiko PBS003. Sedangkan, untuk PBS004, dimensi trading cost berpengaruh pada saat level (t) yang menunjukkan bahwa PBS004 lebih aktif diperdagangkan.

Dimensi market depth berpengaruh signifikan pada Sukuk Negara yang aktif diperdagangkan, seperti PBS004, tetapi tidak signifikan terhadap PBS003 yang kurang aktif diperdagangkan. Dimensi market depth untuk PBSO04 adalah dimensi market depth 4 bulan sebelumnya, yang diduga disebabkan tidak adanya dealer sebagai market maker yang menjadi penggerak perdagangan.

Bond specification yang diwakili oleh kupon dan TTM berpengaruh signifikan terhadap liquidity premium PBS003 maupun PBS004. Namun, untuk PBS003 TTM berpengaruh negatif. Hal ini disebabkan PBSO03 tidak banyak ditransaksikan sehingga berkurangnya TTM tidak disertai dengan menurunnya yield.

Penelitian ini menemukan pula bahwa investor yang berinvestasi pada instrumen keuangan syariah seperti sukuk mempertimbangkan faktor risiko likuiditas dalam menentukan expected return dari sukuk. Lebih lanjut, faktor likuiditas merupakan salah satu faktor pembeda perilaku investor terhadap sukuk dan obligasi, selain faktor kesesuaian terhadap prinsip syariah.

Pemerintah hendaknya melakukan penerbitan Sukuk Negara dengan tenor yang tidak bersesuaian dengan SUN sehingga tidak terjadi arbitrage antara Sukuk Negara dengan SUN. Pembentukan market maker sukuk diharapkan dapat mendorong Sukuk Negara lebih aktif diperdagangkan di pasar sekunder. Selain itu, diperlukan pula strategi komunikasi yang efektif yang melibatkan organisasi, asosiasi, serta komunitas ekonomi dan keuangan syariah kepada masyarakat dan pelaku pasar keuangan, baik domestik maupun asing.

Regulator pasar modal, hendaknya dapat merumuskan pemberian insentif bagi investor Sukuk sebagai upaya menempatkan persepsi tingkat risiko antara SUN dengan Sukuk pada level yang sama di mata investor, walaupun studi Karatas \& Nienhaus (2015) menyimpulkan bahwa membandingkan performa instrumen obligasi dan sukuk di pasar keuangan Malaysia masih menjadi tantangan tersendiri karena adanya bias data di pasar tersebut.

Penelitian lebih lanjut dapat menggunakan faktor lain dalam mengukur pengaruh liquidity premium Sukuk Negara selain faktor yang digunakan dalam penelitian ini. Penelitian lebih lanjut juga diperlukan untuk melihat dampak dimensi likuiditas yang lain seperti resiliency dalam mempengaruhi liquidity premium Sukuk Negara. Penelitian dalam periode observasi yang berbeda dengan kondisi infrastruktur pasar yang berbeda juga dapat dilakukan, termasuk untuk melihat dampak perbedaan infrastruktur pasar seperti regulasi dan fatwa terhadap tingkat risiko likuiditas Sukuk Negara. 


\section{DAFTAR PUSTAKA}

Amihud, Y., \& Mendelson, H. (1991). Liquidity, Asset Prices and Policy. Financial Analysts Journal, 47(6), 56-66.

Amihud, Y., Mendelson, H., \& Pedersen, L. H. (2005). Liquidity and Asset Prices. Foundations and Trends ${ }^{\circledR}$ in Finance, 1(4), 269-364. https://doi.org/10.1561/05000000003

Ariff, M., Chazi, A., Safari, M., \& Zarei, A. (2017). Significant Difference in the Yields of Sukuk Bonds versus Conventional Bonds. Journal of Emerging Market Finance, 16(2), 115-135. https:/doi.org/10.1177/0972652717712352

Ariff, M., \& Safari, M. (2012). Are Sukuk Securities the Same as Conventional Bonds? Afro Eurasian Studies, 1(1), 101-125. https://doi.org/10.2139/ssrn.1783551

Ariff, M., Safari, M., \& Mohamed, S. (2013). Sukuk Securities and Conventional Bonds: Evidence of Significant Differences. Pertanika J.Ournals Social Sciences \& Humanities, 21(2), 621-638. Retrieved from http://www.pertanika.upm.edu.my/

Bank Indonesia. "BI 7-day Reverse Repo Rate". https://www.bi.go.id/id/moneter/bi-7dayRR/data/Contents/Default.aspx. Diakses 19 Desember 2017.

Black, J. R., Stock, D., \& Yadav, P. K. (2015). The Pricing of Different Dimensions of Liquidity: Evidence from Government Guaranteed Bank Bonds (CFR Working Paper, No. 15-10).

Black, J., Stock, D., \& Yadav, P. (2014). The Pricing of Liquidity Dimensions in Corporate Bonds. Retrieved from http://www.efmaefm.org/OEFMAMEETINGS/EFMA ANNUAL MEETINGS/2014-Rome/papers/EFMA2014_0196_fullpaper.pdf

Black, J. R., Stock, D., \& Yadav, P. K. (2016). The pricing of different dimensions of liquidity: Evidence from government guaranteed bonds. Journal of Banking and Finance, 71, 119-132. https://doi.org/10.1016/j.jbankfin.2016.06.008

Blommestein, H. (2017). Impact of regulatory changes on government bond market liquidity. Journal of Financial Regulation and Compliance, 25(3), 307-317. https://doi.org/10.1108/JFRC01-2017-0001

Brugnoni, A. (2008). Shariah governance at work: from asset-based to asset-backed Sukuk. Shirkah, (7), 18-24.

Bunaidy, M. R. (2012). Analisis Deskriptif Likuiditas Obligasi Pemerintah Republik Indonesia (Magister Thesis). Universitas Indonesia, Depok.

Dick-nielsen, J., Feldhutter, P., \& Lando, D. (2012). Corporate bond liquidity before and after the onset of the subprime crisis. Journal of Financial Economics, 103(2), 471-492.

Direktorat Jenderal Pengelolaan Pembiayaan dan Risiko. (2016). Pengelolaan Pembiayaan dan Risiko Keuangan Negara: Praktik-praktik, Strategi, dan Kebijakan. Jakarta.

Direktorat Pembiayaan Syariah. (2017). Laporan Riset Preferensi Investor dan Potensi Permintaan Investor SBSN Tahun 2018 (unpublished). Kementerian Keuangan, Jakarta.

Elton, E. J., Gruber, M. J., Agrawal, D., \& Mann, C. (2001). Explaining the rate spread on corporate bonds. Journal of Finance, 56(1), 247-277. https://doi.org/10.1111/0022-1082.00324

Fabozzi, F. J. (2000). Bond Markets, Analysis and Strategies. New Jersey: Prentice Hall.

Haneef, R. (2009). From “Asset-backed" to "Asset-light" Structures: The Intricate History of Sukuk. ISRA International Journal of Islamic Finance, 1(1), 103-126.

Harris, L. (1990). Liquidity, Trading Rules and Electronic Trading Systems. New York University Salomon Center Monograph Series in Finance and Economics.

Hong, G., \& Warga, A. (2000). An Empiricl Study of Bond Market Transactions. Financial Analysts Journal 56, 32-46.

Indonesia Bond Pricing Agency. Harga dan Yield Wajar Obligasi Pemerintah Indonesia. (unpublished).

Jobst, A., Kunzel, P., Mills, P., \& Sy, A. (2008). Islamic bond issuance: what sovereign debt managers need to know. International Journal of Islamic and Middle Eastern Finance and Management, 1(4), 330-344. https://doi.org/10.1108/17538390810919637

Karatas, A., \& Nienhaus, V. (2015). Comparing Sukūk and Conventional Securities: The 
Challenge of Consistency. Journal of Islamic Banking and Finance, 3(2), 15-23. https://doi.org/10.15640/jibf.v3n2a2

Kyle, A. S. (1985). Continuous Auctions and Insider Trading. Econometrica, 53(6), 1315-1335.

Masitoh, I. (2016). Analisis Pengaruh Likuiditas terhadap Yield Spread Sukuk (Pada Sukuk yang Terdaftar di Bursa Efek Indonesia Periode 2013-2015) (Bachelor Thesis). Universitas Islam Negeri Syarif Hidayatullah, Jakarta.

Mohanty, M. S. (2002). Improving liquidity in government bond markets: what can be done? BIS Papers, 11, 49-80.

Nienhaus, V., \& Karatas, A. (2016). Market perceptions of liquid sovereign sukuk: A new asset class? International Journal of Islamic and Middle Eastern Finance and Management, 9(1), 87-108. https://doi.org/10.1108/IMEFM-03-2015-0027

Nurhasanah. (2011). Hubungan Antara Likuiditas Dan Harga Sukuk Serta Faktor Faktor Yang Mempengaruhinya (Magister Thesis). Universitas Indonesia, Depok.

Pastor, L., \& Stambaugh, R. F. (2003). Liquidity Risk and Expected Stock Returns. Journal of Political Economy, 111(3), 642-685.

Priyambodo, W. B. (2018). Pengaruh Penerapan GCG, Profitabilitas dan Likuiditas terhadap Peringkat Sukuk Korporasi dan Yield Sukuk Korporasi (Bachelor Thesis). Universitas Islam Negeri Sunan Kalijaga, Yogyakarta. Retrieved from http://ejournal.uajy.ac.id/14649/1/JURNAL.pdf

Rifaldi, I. (2014). Faktor-faktor yang Berpengaruh terhadap Harga pada Sukuk Negara Seri Project Based Sukuk di Pasar Sekunder. Universitas Indonesia.

Rosetika, A. (2018). Analisis Faktor-Faktor Internal yang Memengaruhi Likuiditas Sukuk Negara di Indonesia (Bachelor Thesis). Institut Pertanian Bogor, Bogor.

Rouetbi, E., \& Mamoghli, C. (2014). Measuring Liquidity in an Emerging Market : The Tunis Stock Exchange. International Journal of Economics and Financial Issues, 4(4), 920-929.

Siamat, D. \& Suminto. (2015). Sukuk Negara: Instrumen Keuangan Berbasis Syariah. Jakarta: Direktorat Pembiayaan Syariah.

Turner, P. (2002). Bond markets in emerging economies: an overview of policy issues. BIS Papers II, 1-12.

Undang-Undang Nomor 24 Tahun 2002 tentang Surat Utang Negara.

Undang-Undang Nomor 19 Tahun 2008 tentang Surat Berharga Syariah Negara.

Peraturan Bank Indonesia Nomor 17/4/PBI/2015 tentang Pasar Uang Antarbank Berdasarkan Prinsip Syariah. 